\title{
Chaplaincy service in the Army of Republic of Macedonia - requirement, importance and justification
}

\author{
Goran Vasilevski, Ph.D. \\ Ministry of Defense of the Republic of Macedonia \\ E-mail: gvasilevski@yahoo.com
}

\begin{abstract}
Along with self-knowledge, human beings developed awareness of safety and the phenomena that are surrounding them. The awareness of security based on the efforts to survive, resulted in adapting to various tools and their use for individual and collective protection and there are the beginnings of the need for arming and organizing military formations that are part of the base of human civilization. Phenomena that are surroundding, including birth, life and death, contributed to developing awareness that there may be a supernatural or divine force that manages them. Therefore the basic human right to freedom of thought, expression and religion is complementary with the right to freedom and security. Right here, as in the long history of warfares 'in the name of God' lays the relationship between military and religion, regardless of which confession it is. This interdependence of the army with the religion can also be considered absurd and inclusive. Absurd, because the base of every religion is encouraging love and understanding, and the armies and their weapons are used for killing and destruction. It is Inclusive because religious members of the armed forces have need of spiritual justification of the call they chose as professional determination.

The biggest challenge of this paper is the observation of the decisions on this issue in countries that have a long tradition of involvement of clergy within the armed forces, the armies of countries transiting from one ideological system to another, as well as possible solutions for introducing clerical service in countries whose armed forces are made up of members of several confessions. In this context will be considered the need and justification for introducing chaplaincy service in the Army of Republic of Macedonia.
\end{abstract}

Keywords: religion, faith, armed forces, religious identity, chaplaincy service, spiritual support.

\section{Introduction}

The historic stamp on military and war is next to the symbol of admiration of the supernatural in the encyclopedia of ever known human civilization. The legends and myths of alive and disappeared nations abound with descriptions of gods or divinities with alien force, so therefore, the cult is considered as a precondition for success and victory on the battlefield. At this point 
the characteristic symbols engraved for combative events of the known civilizations on several continents. Moreover, these symbols are considered as one of the oldest documented data on the relationship between God and armies.

Identical is the case with written content, whether it comes to religious works such as the Bible and the Koran, or literary works as Homer's Iliad, where armies and wars are in direct proportion to a particular Cod or divinity. Unlike existing data for Crusades (in XI and XII century), where warfare is in explicit relationship with the religious determination of the warring parties (Smail R.C, 1995), the historical contents of the new era based on clearly indicated facts, the military and war put in tight, but not in a completely direct constellation with faith or religion.

A significant part of the soldiers, as part of the written human history with bloody wars, except the belief in personal military skills and strength of the army, while leaving in the battle, before or during combative actions they felt themselves in need of spiritual help and protection of a particular supreme force. Supernatural assistance and protection are considered for support especially in the difficult times of facing death, also represents hope for survival and victory over the enemy. This act is primarily a spiritual instinct of the inner being that in critical moments is stronger than logic. Realizing the need of spiritual support for the soldiers, tribal leaders placed people for performing the rituals with spiritual symbolism. Clerics have been present since ancient armies, and with the development of civilization was transferred the ratio of spirituality with the military, which persists today.

In many modern armies where is practiced clerical service (further named as chaplaincy service), the prescribed articles are prohibiting clergyman in uniform to carry or use weapons. After all, the relationship of the army with the priesthood today is based on the legal regulation in which the country regulates the relationship with religious communities. But the need for chaplaincy service in the armed forces in many ways is different to their role in public life. The simple reason is that the army duty often implies involvement in a stressful environment, and a tendency to be away from the family for long time. In such an environment where is increased the possibility of facing death, the religious soldiers needs spiritual support. In fact, the military statement: 'In military trenches there are not atheists" comes from the experience and close contact with death during the wars.

Today is easy to doubt in faith or to deny the existence of God, disputing the scientific data on the origin and evolution of life on the planet Earth. But this paper has no intention of favoring theological opposed Darwin's theory on the origin of the world, but to determine whether there is a need for spiritual support among religious oriented army personnel and therefore, to see the justification for introducing (or not introducing) the chaplaincy service among the armed forces of the Republic of Macedonia.

\section{The relationship of religion and faith with the country and the armed forces}

According theological learning man is created by God according to his character and opportunity. The terms 'figure' and 'shape' are considered from different aspects. One of the aspects 


\section{Security}

believes that 'figure' refers to the body and appearance of God, and that 'shape' refers to soul. The different access points that 'figure' marks the nature of man, while 'shape' is a description of the supernatural in man, but both aspects emphasize the close relationship of man with Cod. This doctrine is of supreme importance for theology because according to herrepose human character and his relationship with God.

Otherwise said, the figure of God in man is the essence that makes it different from other animals and beings. (Berkof L, 1996). It is important to note that this theological approach is valid mostly in the Christian, Jewish and Islamic religion. In other religions (Hinduism, Shintoism, etc.) the theological approach is basically different because of the existing polytheism, while Buddhism and Chinese religious tradition is considered more a philosophy and way of life than a religion.

At the same time, nowadays there is a widespread agreement that Darwin's theory on the origin of species and natural selection has a significant impact on people's understanding of their own identity and the place he has in the universe. Namely, despite the established belief that ruled until the middle of XIX century, that God is the Creator of the earth and everything that is on it, the theory of Charles Darwin (1809 - 1882) is based on evolution as main reason for the creation of the world and life on it.

Regardless of the origination approach, the man was put in the center in the ancient and modern world. This approach leads to the appearance of anthropology, whose primary interest isman as a human being that has a body, soul and spirit. Therefore, according to anthropologists (who in the past cultivated sense of moral, intellectual, cultural and military superiority), the man is physically, mentally and spiritual being, that the spiritual awareness separates him from wildlife (Barrett.S.R. 2009). Exactly the spirituality is a dimension that owns each person, whether it is religious or atheistic person. Max Scheler believes that 'body and soul does not reflect the current contradiction in man, but the contradictions that lie in man are deeper, considering the physical and spiritual life.' (M.Scheler, 1987).

Religion is closely related to man, for the simple reason that almost there is no culture in which there was no particular religion. Almost all aspects of life, more or less rely on the spirituality, although basically the concept of religion is very different according to its flexibility and spiritual connections to the individual or group. Anthropology indicates that the religion is a product of human tendencies, desires and ideals.

According to some authors, the attempt to define religion is equal to the attempt to define love, because religion as well as love has different meaning for each person separately, and its understanding is mystery (Hill B.R.; Knitter P.F.; Madges W, 1997). Basically, religion is a set of dogmas and regulations that require a defined code of behavior towards that cult, or a system of belief and ritual ceremonies by which a person or community are made according to the supernatural. In fact, religion is an external manifestation of the spirituality as deep inner need of man to be part of the absolute and eternal. As an external expression of faith, the religion is the only way to God, or a way of communicating with the Almighty, and the way and manner of communication can not and must not be more important than God (Есад Бајтал, 2005).

Phenomenon itself is a multitude of religions, which are developed under the influence 
of geographical factors and historical moments, depending on the success of the demonstration and the imposition of a particular way of approximation to the divine. Certainly, influence has the different social order, lifestyle, or different culture. Also fenomoen is the success of religion in a particular historical moment to unify such diversity. Because there are many religions, whose approach to satisfy human spirituality is different, to the religion should be seen as a multilayered question. A cautious approach is required mostly because of the danger of manipulating with the existing religious differences that are easily transformed into cultural and ethno-national divisions. These divisions may rise to the level that can completely capture the free consciousness. Also, this is one of the aspectswhy Karl Marx considers religion as 'opium'which puts man in a state of lack of sensitivity, allowing his manipulation (Rott M.0, 2007).

Ironically,ly, the religion in certain historical periods is trying to deny or relative scientifically proven knowledges, ${ }^{61}$ because science contributes to the country to be almost completely released from the influence of religion. However although today, global world is more secular than ever before, religion succeeds to keep its place in it through the role of merging and separating of civilizations. Namely, if the global culture and global society are perceived as secular, it would mean a misinterpretation of current world history. In this context, P.Bejer and L.C.Biman suggest that 'religious views and religious people can not understand eachother, without previously understanding of the religious character of world culture and societies in it' (Beyer P.; Beaman L.G, 2007). In addition, the superiority of science, economy and secularism over religion in the modern world, are not obstruct for the appearance of 'new' religions, indicating that man is not requiring only scientific and logical interpretation of phenomena and events that surround him.

The faith, unlike religion is unique capacity of man. As being characterized by a deep individual dedication to personal determination for belief, the faith in one person can be on several levels: intellectual, emotional, physical or imaginary. The human faith does not include only the knowledge, but also feelings, decisions and actions.

In fact, faith is energy and driving force that inspires human life, representing a sense which perceives the need for intensive search of the ideal of truth (Hill B.R.; Knittrer P.F; Madgtes $V$, 1997). Therefore, religion is a human tendency for approximation to absolute happiness and release from all kinds of suffering and should be distinguished from religion and religiosity that is often empathed. But the science and economics of the modern world, despite religious, more narrow the spiritual space. Percepting this point, J. Ratzinger(former superior of the Catholic Church), believes that there is a large gap between the world of faith and the world of science, whose bridging is becoming less possible (Ratzinger J.; (Pope Benedict XVI, 2009).

The faith seen as a base of religion is a psychological fact, but it is not deprived from philosophical elements. But the contradictions between Christian faith and scientific knowledge are deepening because religion and science tend to completely different purposes. The Christian faith has its own subject that is the area of the spirit, revealing the truth about the situations and states appropriate to the human soul (Archbishop Anthony).

\footnotetext{
${ }^{61}$ When in 1633 the Inquisition forces Galileo Galilei to give up the heliocentric theory of Nicolaus Copernicus.
} 


\section{Security}

Considering the stated aspects, can be indicated that the religion is an intimate human category, i.e. internal spiritual instance looking for truth which is not always a synonym for religiosity. Unlike the religious dogma or scientific laws, religion as an individual category is free and does not aim to prove. Therefore, religion can be represented as a border of the scientific and religious differences.

\section{- The relationship between religion and state}

State and religion have always been in appropriate correlation that dimensioned depending on the historical period. Description of this relationship give the gospels from the New Testament, where it is pointed out that the empire belongs to the king, and divine of God (Gospel of Matthew). Of course, this is too much simplified categorization of the relatively complex relationship between religion and country. Namely, religion as one of the oldest organized civilization forms has always had a significant impact on public authorities, occupying adequate space on the political scene. Therefore, religion has had a significant contribution in the creation of national countries in the world.

However, in the late 40 s and early 50 s of last century, the influence of religion in policy creation in the states appreciably weakened. The most characteristic example were (are) states built on socialist ideology. As one of the more interesting, can serve the example with NR.Albania, where in the preamble of the constitution of 1976, it is stated that: 'the period of religious ghastliness is finished, and the consciousness of the working people is modeled according to the ideology of the proletariat.' This constitution did not accept any religion and prohibited any kind of religious organization. With these constitutional provisions, the former NR Albania is considered as first atheist country in the world (Ferrari S.; Durham W.C. Jr.; Sewell E.A, 2003).

These factors set the specifics for editing the relationship with religion in any of the postcommunist countries separately, as is evident the different degree of its involvement in cultural, social and political events of the country. But, the regulation of relationships between the country and religion is not characteristic only for countries that transited from one to another form of organization. Namely, there are as many different approaches to the management of the relationship with religion, as there are countries. (Ferrari S., Cristofori R, 2010).

In some countries, the religious orientation of majority of the population has received status of a state religion, and the religion enjoys special privileges, while other countries have established a clear legal distinction between the country and religion. In truth, today states are characterized as multiethnic and multi-confessional, as well as there is more evident tendency of some countries to put the religion on the margins of the society. ${ }^{62}$ This situation mainly arises from the trend of globalization, which imposed conditions that are challenge to the states, putting on further examination the religion's ability to adapt to the new culture of life. In modern countries,

\footnotetext{
${ }^{62} \mathrm{As}$ an example can serve the decision of the administration of USA, in which in the field of human rights, the right of LGBTminorities is stated before the freedom of religion.
} 
religious communities don't have influence on the design or implementation of national policy or vice versa. ${ }^{63}$

The relation state-religion in Republic of Macedonia is formally regulated by constitutional provision and separate legal regulation. Namely, the highest legal act of Republic of Macedonia guarantees freedom of religion and freedom to publicly, individually or in a community with other, expressing the faith. It further states that religions, religious communities and groups are separated from the state and are equal in front of the law (Official Journal of Republic of Macedonia; 2003).

Detailed presentation of the relationship between the state and religion is specified with the law for legal status of church, religious community and religious group, applicable from 01.05 .2008 (Official Journal of Republic of Macedonia, No. 35/97). Legal provisions emphasize the secularity of Republic of Macedonia, which means that religion is separated from the state. It involves noninterference of state in religious activities nor of religion in public activities.

Also, the legal regulation establishes legal person responsible for mediating in the regulation of the relationship between the country and the religion, and is presented to the commission for relations with religious communities and religious groups (Official Journal of Republic of Macedonia", 2000). In the description of the legal authorizations and responsibilities of thislegal person, it is stated mediating in cooperation of the country with the religious subjects, as it is pointed out the cooperation with the Ministry of Finance, Ministry of Culture, Ministry of Internal Affairs and Ministry of Foreign affairs, Ministry of Justice, Ministry of Education and other institutional subjects. Valuable for note is that during job descriptions and responsibilitiescommission does not state cooperation with Ministry of Defence or the Army of Republic of Macedonia.

\section{- The armed forces and their relationship with religion}

Armed forces are well organized, politically and socially conscious ethnicity, which together with other social groups is an actor in the socialpolitical arena. They are trained for eventual use of force when there is need to protect the nation from external aggression or internal violence. The military is subordinated to state institutions and should be distanced from the areas of political decision-making, although as a social subject, represents an instrument of politics. Specifically, the political subordination of the military doesn't mean its loyalty to a particular mode or politic party and ideology, but submission to constitution and the law (Vankovska, 1997). However, can be said that soldiers have always felt the need of blessing for selecting its call, especially when leaving in war (excluding warfares stimulated by ideological motives).

The relationship of religion with AF (Armed Forces) today is based on legislation according which are defined the relationships with the state, stating that it is an indirect relationship, except when it is a question of the armed forces of the Vatican as the smallest official army in the world.

Social development has imposed the need for distribution of power in the countries (legislative, executive and judicial), from which arose the need of normative regulation of the rela-

${ }^{63}$ This does not refer to countries like Vatican and Iran, they are based on religious fundus. 


\section{Security}

tionship of the country with its subjects, including religion. Therefore, gradually was editing the relationship of religious communities with the armed forces, which was defined depending on the way that chose the state. In principle, the part that regulates the relationship between AF and religious communities in a country, is contained in the law for defense, or the law for armed forces, where are given details about the relationship of armed forces and religion.Most countries in the world have precisely defined relation of its armed forces with the dominant religious communities, balanced with appropriate primary and secondary legislation. This regulated relationship allows practicing confessional commitment of military personnel, as well as the presence of religious communities in the ranks of the army.

\section{As it was already mentioned, Republic of Macedonia has no standardized relationship between religion and army.}

\section{Chaplaincy service in the armed forces}

The regulation of chaplaincy service in the armed forces gets legitimacy from the national constitution and is in accordance the applicable legislation of a country. This means that according to various constitutional and legislative solutions, there are various examples in the approach to this issue. Examples are countries with professional armies and countries where serving in the military is a regular civil obligation. Particularly interesting is the case with regulation of chaplaincy service in the armies consisting of members from several confessional groups.

Wearing military uniform certainly does not reduce the need for spiritual support, regardless of whether it is needed in peacetime or in conditions of war. The approach to this issue in the armed forces of the countries at the international level is different, as is different the concept according to which chaplaincy services are part of the defense and military structure. Namely, while in some countries (Germany, Slovakia, Bosnia, etc.), chaplaincy service is incorporated as part of the organizational and formational structure of army units, in others (Austria, Hungary, Italy, etc.) these services are a separate part.

As has already been mentioned, in general chaplaincy service in the armed forces is regulated in a manner consistent with the Constitution and the valid legislation, but certainly should be considered the military tradition, and current political, social and cultural conditions in society. When is mentioned the Constitution, it should be emphasized that most countries that have normative regulation of chaplaincy service in the armed forces are declared as secular societies. It means that the chaplaincy service in the defense and military have no other function than to care for the spiritual support of religious army members observing their guaranteed right to freedom of religion.

At the same time, should be noted that according to military priests, regulations of most armies around the world prohibit these persons to carry or handle weapons, even when they are present on the battlefield. On the other side they must meet certain additional criteria that are not required for priests who serve in the civilian part of the society. 


\section{Security}

\section{Requirement and opportunities for introducing chaplaincy service in the armed forces of Republic of Macedonia - results of conducted research}

Macedonian constitution guarantees freedom of religion, public individual or group expression of religious determination. Also, the same provision of the highest constitutive act emphasizes that all religious communities and groups are separate from the state and equal in front of the law (Constitution of Republic of Macedonia, Article 19).

The most common religions in Republic of Macedonia are Orthodox Christianity and Islam. According to the official data from the last completely conducted census in Republic of Macedonia, as Orthodox Christians have been declared 1,310,184 out of 2,022,547 inhabitants, that is approximately $65 \%$ of the total population, for Muslims have been declared 674,015 people, or approximately $33 \%$. As Catholics have been declared 7.008 , or $0.34 \%$, while as Protestants have been declared 520 people. The number of citizens, who identified themselves as members of other religions or atheists, was 30.820 people, or approximately $1.5 \%$ of the total population (State institution for statistics).

According to the projected national strategy, the Army of Republic of Macedonia (ARM) has approved 8133 active military personnel with maintenance of minimum complementing of $90 \%$ (7320 members). Also, the military complementing in June 2012 was 6.952 persons ( $85.5 \%$ complementing), while the complementing in the Ministry of Defence in the same period was 976 persons (of which 197 military personnel) (White Book on defense, 2012). Currently there are not reliable data with valid percentage of religious orientation of the active members of Army of Republic of Macedonia (ARM).

The chaplaincy serviceis not included in the army because of the lack of tradition for mutual respect between religious institutions and the armed forces inthis country, which is mostly a result of the postwar ideological and historical heritage of this region. Namely, during the NLW (National Liberation War of Macedonia) active participation in Macedonian partisan formations in NLM (National Liberation Movement) had a number of clergymen. One of them was the priest Kiril Stojanovski who with the involvement in NLM (National Liberation Movement), became brigadeclergyman in the First Macedonian NLB (National Liberation Brigade), and a member of thereligious Committee in the headquarter of NLW (National Liberation War)and also was participant of first assembly of AANLM (Anti-fascist Assembly for the National Liberation of Macedonia). Another example has the character of priest Metodi Gogov who had an active role in helping the Macedonian liberation movement and was also a member of AANLM (Anti-fascist Assembly for the National Liberation of Macedonia). Also, priest Gogov, later called Archbishop Michael, was the first superior of Macedonian Orthodox Church in independent Republic of Macedonia. However, since its independence, in Republic of Macedonia has not been taken any concrete steps in the regulation of normative framework that will more closely determine this area.

The initiating attempts to introduce the priest service in ARM as practice(that is already applicable in most NATO armies), havenot concrete efforts to regulate the normative framework in this sphere, and there is not adequate result. At this moment, as opposed to other republics in 


\section{Security}

the former SFR Yugoslavia, only Republic of Macedonia and Montenegro have legally regulated relations between the armed forces and religious communities.

In order to see whether there is a need to implement the chaplaincy service in the armed forces of Republic of Macedonia it is conducted an anonymous survey among the active composition of ARM, covering several groups of participants.

\section{Results of the survey}

According to the results of the anonymous survey questionnaire designed for the needs of the labor 'Chaplaincy service in the armed forces of Republic of Macedonia - requirement, importance and justification ' can be stated the following:

The total number of respondents is 58. The questionnaires are in Macedonian and Albanian language, also is performed certain determination of interviewees in two sub samples. First with a total number of 38 respondents (questionnaires in Macedonian language) and second with a total number of 18 respondents (questionnaires in Albanian language)

Survey question no. 1 (Figure No. 1), according to which is determined ethnicity. According to statements given by the frequencies of respondents, the most are Macedonians 67\% (38), Albanians $31 \%(18)$ and Serbian $2 \%(1)$.

\section{Figure no. 1}

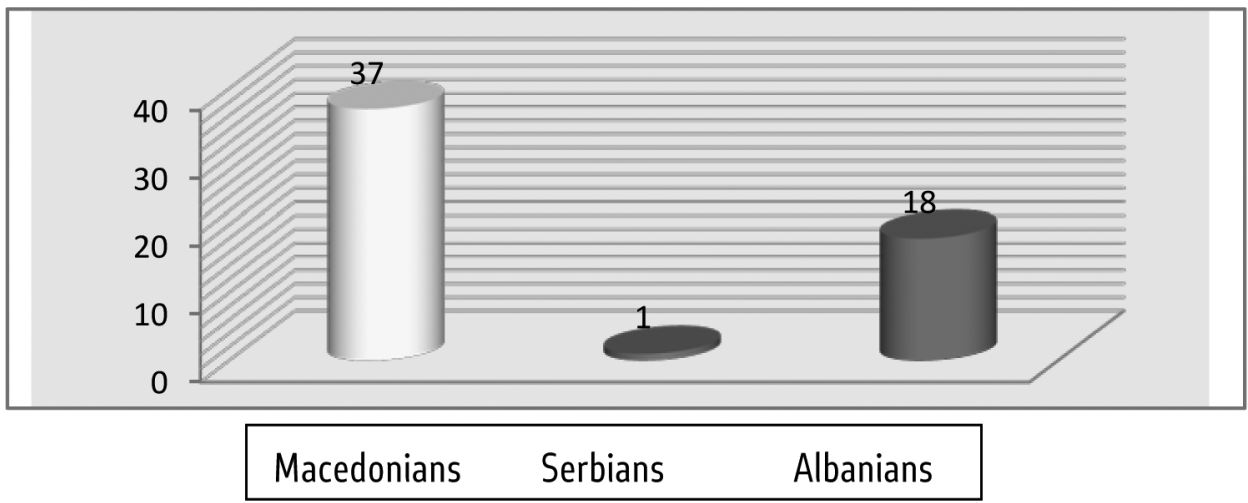

Survey question no.4 gives information for the religiosity of respondents. From the total number of respondents can be concluded that 95\% (53)are religious and only 5\% (3) are not religious. Therefore, from the total number of respondents of the Christian faith $35(92 \%)$ expressed that are religious, while only $3(8 \%)$ of respondents gave a statement that they are not religious. Respondents of the Muslim religion on this question of religiosity gave $100 \%$ religious statement.

According to the values of chi - square test (Table 1) between the expected statements with thestatement frequencies of the respondents, can be concluded that there are statistically 
significant differences, it cen be noticeably from the calculated values of $(1, n=56)=7504, p=$ 0.006 (Sig.= .006).

\section{Table no. 1}

VAR00001
\begin{tabular}{|l|ccc|lc|}
\hline & Observed N & Expected N & Residual & & VAR00001 \\
\hline No & 3 & 11.2 & -8.2 & Chi-Square(a) & 7.504 \\
Yes & 53 & 44.8 & 8.2 & df & 1 \\
Total & 56 & & & Asymp. Sig. & 0.006 \\
\hline
\end{tabular}

The survey question no. 6 (Table 2.) gives information about the place that religion has in life, according to the calculated values of chi - square test was concluded that there are statistically significant differences in the frequencies of the statements of participants, it is noticeably from the calculated values of $(3, n=56)=21.143, p=0.000$ (Sig. $=.000$ ). The majority of respondents $43 \%$ (24) reported that religion occupies a very important place in life, and only $3.5 \%$ (2) consider religion as unimportant.

\section{Table no. 2}

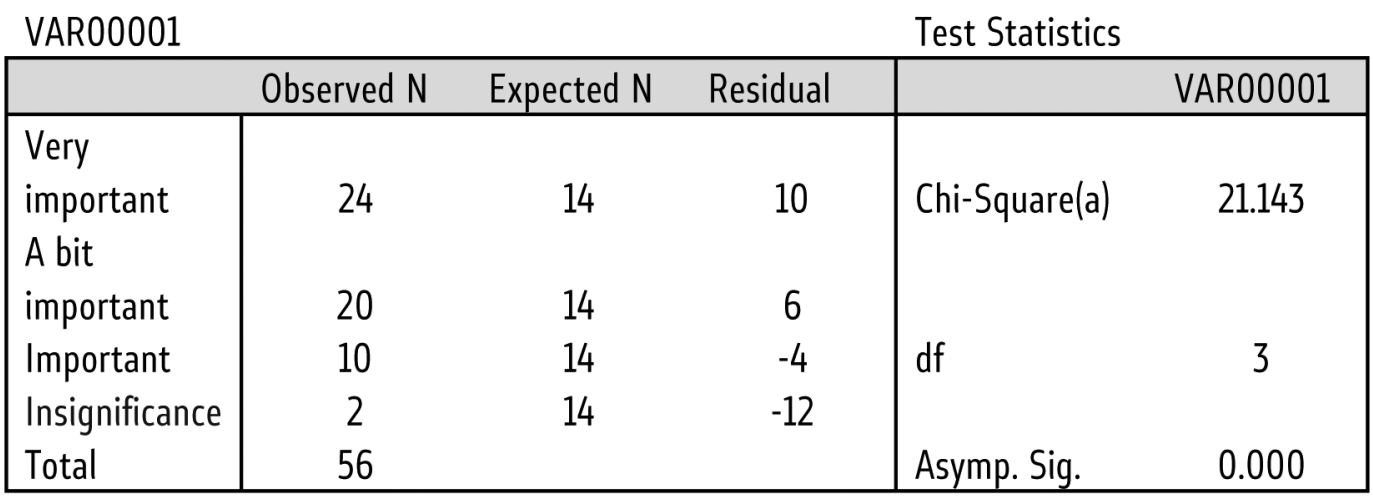

Survey question no. 8 (Table no.3) gives answer to the question'What kind of believer do you think you are?' According to the received values on chi - square test was concluded that there are statistically significant differences in the frequencies on the statements of participants, it is noticeablyfrom the calculated values of $(4, n=53)=43.132, p=0.000$ (Sig. $=.000)$. $0 n$ the eighth survey question statements gave 53 respondents according to which mostly, $53 \%$ (28) have expressed that they believe in what their religion preaches. On the statement that there is no God or supernatural force did not respond any respondent, and on the statement 'I have not determined' responded one respondent or $2 \%$ of the total number. 
Table no. 3

VAR00001
\begin{tabular}{|l|ccc|lc|}
\hline \multicolumn{2}{|c|}{ Observed N } & Expected N & Residual & & VAR00001 \\
\hline 1 & 28 & 10.6 & 17.4 & Chi-Square(a) & 43.132 \\
2 & 13 & 10.6 & 2.4 & & \\
3 & 4 & 10.6 & -6.6 & $\mathrm{df}$ & 4 \\
5 & 1 & 10.6 & -9.6 & & \\
6 & 7 & 10.6 & -3.6 & & 0.000 \\
Total & 53 & & & Asymp. Sig. & \\
\hline
\end{tabular}

1 - I believe in everything that my religionpreaches

2 - I believe in some of what my religion preaches

3 - I believe in God and the supernatural forces but do not believe in any religion

4 - I think there is no God or supernatural forces

5 - I am undecided

6 - I do not consider myself as a dedicated believer

Survey question no. 12 (Table no.4), gives information for the need for introducing clerical service in the army. According to the received values on chi - square test was concluded that there are statistically significant differences in the frequencies of the statements of participants, it is noticeably from the calculated values of $(3, n=53)=9.566, p=0.023$ (Sig.=.023). From the total number of respondents to this question answered 53 respondents. According to the statements $42 \%$ (22) are for introducing ofclerical service in the army against $26 \%$ (14) who think that there is no need.

\section{Table 4}

VAR00001
\begin{tabular}{|l|ccc|lc|}
\hline & Observed N & Expected N & Residual & & VAR00001 \\
\hline Yes & 22 & 13.25 & 8.75 & Chi-Square(a) & 9.566 \\
No & 14 & 13.25 & 0.75 & & \\
Maybe & 7 & 13.25 & -6.25 & df & 3 \\
Don't have & & & & & \\
opinion & 10 & 13.25 & -3.25 & & 0.023 \\
Total & 53 & & & Asymp. Sig. & \\
\hline
\end{tabular}




\section{Security}

Survey question no. 15 (Table no. 5), for the help of clerical services in support of army command staff in determining the religious needs of the believers in the army ranks, as well as giving spiritual support in case of severe injuring, disease or death of military personnel (or close person to them). According to the received values of chi - square test was concluded that there are statistically significant differences in the frequencies of the statements of participants, it is noticeably from the calculated values of $(3, n=53)=12.736, p=0.005$ (Sig. $=.005)$. Of the respondents that answered this question the majority or $43 \%$ have opinion that the clerical services may be useful for the military command personnel and for providing spiritual support.

\section{Table no. 5}

VAR00001

Test Statistics

\begin{tabular}{|c|c|c|c|c|c|}
\hline & Observed N & Expected $\mathrm{N}$ & Residual & & VAR00001 \\
\hline Yes & 23 & 13.25 & 9.75 & $\begin{array}{l}\text { Chi- } \\
\text { Square(a) }\end{array}$ & 12.736 \\
\hline No & 15 & 13.25 & 1.75 & & \\
\hline $\begin{array}{l}\text { Don't have } \\
\text { opinion }\end{array}$ & 6 & 13.25 & -7.25 & $d f$ & 3 \\
\hline Don't know & 9 & 13.25 & -4.25 & & \\
\hline Total & 53 & & & Asymp. Sig. & 0.005 \\
\hline
\end{tabular}

\section{CONCLUSION}

According to the results of the survey we can perceive several conclusions. First, from the received statements of the respondents in the survey can be concluded that army members are religious and the family has the biggest impact on religious beliefs. The received indicators indicate that many respondents in the presence of religious services would find spiritual support. The opinions and attitudes of respondents for the need of introducing clerical service in the army are different, but in a significant number of respondents agree that such an incorporation of service in the army would be useful. Also, according to the results of respondents the clerical services can be useful for the military command personnel.

According to the received indications of the applied system survey questions, can be concluded that the respondents from the Christian and Muslim religion in certain opinions and statements about the requirement, importance and justification of introducing clerical service in the armed forces of Republic of Macedonia are unique in high percentage.

From the presentedcan be concluded that the analysis of processeded indicators of the answers, respondents give a positive signal for the justification of the introduction of clerical service in the armed forces of Republic of Macedonia. Also indicator for that is the expression of the 
members for the religiosity. This very high percentage of religiosity among military members ( $92 \%$ Christian religion and Muslim 100\%), may constitute sufficient base to devote adequate treatment of the indicated area. Particularly, if we take into account the long-term engagement of the army personnel in missions outside the borders of Republic of Macedonia and the stressful conditions they are facing there.

\section{REFERENCES}

1. Barrett.S.R. "Antropology: AStudent's Guide to Theory and Method"; second edition; University of Toronto; Toironto; 2009

2. Beyer P.; Beaman L.G.;"Religion, Globalisation,Culture";Koninklijke Brill NV;Leiden, Netherlands; 2007

3. Berkof L. "Systematic Theology", New combined edition,Wm.B. eerdmans Publishing; 1996

4. Ванковска Б. „Политички систем“, Бомат Графикс, Скопје, 2007

5. Cumper P., Lewis T.; "Religion, Rights, and Secular Society-European Perspectives";Edward Elgar Publishing Inc, Northampton 2012

6. Ratzinger J.; (Pope Benedict XVI; ) "Faith and the Future"; Ignatius Press; San Francisko

7. Rott M.0..; "The Future of Religion: Toward a Reconciled Society"; Koninklijke Brill NV; Leiden; 2007

8. Scheler. M "Položaj čovjeka u kosmosu- Čovek i provijest"; Veselin Masleša; Sarajevo; 1987

9. Slomovitz A.I. "The fighting Rabbis: Jewish Military Chaplains and American History"; New York Univestity Press; New York; 2001

10. Smail R.C. "Crusading Warfare 1097-1193"; Second edition; Cambridge University Press;New York; 1995

11. Hill B.R.; Knitter P.F.; Madges W. "Faith, Religion\&Theology: A Contemporary Introduction"; Twenty-Third Publication;USA; 1997

12. Ferrari S.; Durham W.C. Jr.; Sewell E.A. "Law and Religion in Post-Comunist Europe";Peeters; Leuven; 2003

13. Cepar D.; "Duhovna oskrba vojakov v Evropi in Natu s poudarkom na ureditvi duhovne oskrbe katoličanov" Mednarodno primerjalna študija, 1. Del, Ljubljana; 2010

\section{Journals and publications}

1. Бела книга на одбраната; Министерство за одбрана на Република Македонија; Скопје 2012

2. Др. Есад Бајтал „Политика религиозног конфликта-разлика између вјере и политике" Сараево

3. Vukomanović M.; "Religija, konflikt, identitet"; Individualni I kolektivni identitet u postkomunizmu; Filozofija i društvo; Institut za filozofiju i društvenu teoriju; Beograd; 2000 
4. Department of defence; "Accomodation of Religious Practices Within Military services" DOD Instruction 1300.17

5. Лазаревиќ Л. "Православна црква и војно дужебрижништво", Зборник радова са округлог стола, "Имамска Служба у Војсци", Ел-Калем, Војно Муфтијство; Сарајево; 2009

\section{Internet sources}

http://www.bbc.co.uk/religion/religions/christianity/priests/armychaplains 1.shtml\#h2 http://preminportal.com.mk/content/view/438/71/ http://kovz.gov.mk/?ItemID=1906BEA071923A40B2ECFB5752517506

http://www.todaysmilitary.com http://klin-demianovo.ru/http:/klin-demianovo.ru/novosti/70008/svyashhennikov-ostavyat-v-armii-na-dogovore/

www.bundeswehr.de

http://www.fzs.ba/popis.htm http://mod.gov.ba

http://www.stat.gov.mk/Publikacii/knigalX.pdf 